Jurnal MAKSIPRENEUR, Vol. VI, No. 1, Desember 2016, hal. 37 - 54

\title{
TINGKAT KEPUASAN WISATAWAN DOMESTIK TERHADAP CANDI PRAMBANAN DAN RATU BOKO DI KABUPATEN SLEMAN DAERAH ISTIMEWA YOGYAKARTA
}

\author{
Jemadi (jemadi08@yahoo.com) \\ Bambang Sugeng D. (bsugengd@yahoo.co.id) \\ Fakultas Ekonomi Universitas Proklamasi 45
}

\begin{abstract}
This study will analyze the level of satisfaction of domestic tourists to Prambanan and Ratu Boko temple for services and facilities provided by Prambanan and Ratu Boko temple to domestic tourists consisting of entrance fee, temple beauty, service, security, and promotion from Prambanan temple And Ratu Boko who can make the tourists feel satisfied that encourages the desire to return again on another occasion.

The population in this study were all visitors of Prambanan Temple and Ratu Boko Temple in Sleman District of Yogyakarta Special Region, and samples taken 100 people by using Accidental Sampling Method in sampling, that is make the sample of people who by chance found in the place of research. In this research showed that the level of satisfaction of domestic tourists to the temple of prambanan and queens boko based on entrance fee 3.72 (satisfied); The beauty of temple 4.40 (very satisfied); Service 3,50 (satisfied); Security 3.55 (satisfied); 3.20 promotion (less satisfied). In general, the satisfaction level is in the satisfied category because the mean value of aritmatic is 3.674 (satisfied). While the most dominant factor contributing to the level of domestic tourist satisfaction of prambanan temple and queens boko in Prambanan Sleman Yogyakarta is the beauty with arithmetic mean value 4.40 (very satisfied)
\end{abstract}

Keywords: satisfaction; domestic tourists

\section{PENDAHULUAN}

Dewasa ini pemerintah gencar melakukan pembangunan di berbagai bidang dalam upaya meningkatkan kesejahteraan rakyat. Pelaksanaan pembangunan ini salah satunya adalah melalui pembangunan di bidang kepariwisataan. Pembangunan kepariwisataan terus digiatkan dengan mengembangkan serta mendayagunakan sumber dan potensi pariwisata yang ada. Di Kabupaten Sleman banyak potensi wisata yang dapat dikembangkan untuk mendukung berkembangnya perekonomian setempat, antara lain: wisata pendidikan, wisata sejarah, wisata minat khusus, wisata alam, wisata religi dan bahkan mulai muncul adanya desa wisata di berbagai tempat dan lain sebagainya.

Pariwisata merupakan suatu produk jasa yang dapat ditawarkan ke pasar, dengan berbagai macam promosi sehingga dikenal oleh calon wisatawan. Untuk dapat menarik dan meningkatkan jumlah wisatawan yang berkunjuung maka perlu adanya pemasaran pariwisata. Pemasaraan merupakan suatu proses sosial dan manajerial di mana seseorang 
atau kelompok memperoleh apa yang mereka butuhkan dan inginkan melalui penciptaan dan pertukaran produk serta nilai (Basu Swasta DH dan T. Hani Handoko, 2000).

Salah satu unsur bauran pemasaran paling berpengaruh terhadap perilaku konsumen adalah bauran pengelolaan produk. Pengelolaan produk dalam hal ini lebih menekankan bahwa konsumen (wisatawan) memerlukan jenis-jenis jasa dan fasilitas pelayanan tertentu, sehingga wisatawan dapat merasakan atas jasa dan fasilitas yang diberikan oleh pengelola obyek wisata. Akhirnya wisatawan dapat mengukur tingkat kepuasan atas jasa dan fasilitas yang diberikan pada saat kunjungan wisata. Penelitian ini akan menganalisis tentang tingkat kepuasan wisatawan domestik terhadap Candi Prambanan dan Ratu Boko atas jasa dan fasilitas yang diberikan oleh Candi Prambanan dan Ratu Boko terhadap wisatawan domestik yang terdiri dari biaya masuk, keindahan candi, pelayanan, keamanan, dan promosi dari obyek wisata candi Prambanan dan Ratu Boko yang dapat membuat wisatawan merasa terpuaskan sehingga mendorong keinginan untuk kembali lagi pada kesempatan yang lain.

Dari berbagai obyek wisata candi, Candi Prambanan dan Candi Ratu Boko termasuk obyek wisata yang cukup terkenal, di Kabuapten Sleman Daerah Istimewa Yogyakarta. Berdasarkan data pada tahun 2013 kunjungan ke Candi Prambanan dan Ratu Boko sebanyak 72.680 pengunjung hal itu menunjukkan bahwa Candi Prambanan dan Ratu Boko memiliki daya tarik yang besar di mata masyarakat, hal ini tidak terlepas karena Candi Prambanan dan Ratu Boko memiliki legenda dan juga bernilai sejarah. Atas koordinasi dan campur tangan Dinas Pariwisata Kabupaten Sleman yang tergabung dalam kepengelolaan Wisata Candi Borobudur Prambanan dan Ratu Boko, tingkat kunjungan wisatawan ke Candi Prambanan dan Ratu Boko sampai sekarang tetap tinggi. Berdasarkan uraian tersebut di atas maka perlu dilakukan penelitian mengenai "Tingkat Kepuasan Wisatawan Domestik Terhadap Candi Prambanan Dan Ratu Boko Di Kabupaten Sleman Daerah Istimewa Yogyakarta". adalah:

Atas dasar latar belakang tersebut, maka perumusan masalah dalam penelitian ini

1. Bagaimanakah karakteristik wisatawan domestik yang berkunjung ke obyek wisata Candi Prambanan dan Ratu Boko, Kabupaten Sleman Yogyakarta?

2. Sampai di manakah tingkat kepuasan wisatawan domestik terhadap obyek wisata Candi Prambanan dan Ratu Boko di Kabupaten Sleman Daerah Istimewa Yogyakarta?

3. Jasa dan fasilitas apakah yang paling tinggi menyumbang tingkat kepuasan wisatawan berkunjung ke obyek wisata Candi Prambanan dan Ratu Boko di Kabupaten Sleman Daerah Istimewa Yogyakarta?

Tujuan yang ingin dicapai dalam penelitian dengan judul: Tingkat Kepuasan Wisatawan Domestik Terhadap obyek wisata Candi Prambanan Dan Ratu Boko Di Kabupaten Sleman Daerah Istimewa Yogyakarta ini adalah untuk:

1. Mengetahui karakteristik wisatawan yang berkunjung ke obyek wisata Candi Prambanan dan Ratu Boko, di Kabupaten Sleman, Yogyakarta.

2. Mengetahui tingkat kepuasan wisatawan yang kerkunjung ke obyek wisata Candi Prambanan dan Ratu Boko di Kabupaten Sleman, Yogyakarta.

3. Mengetahui jasa dan fasilitas layanan yang paling dominan memberikan sumbangan terhadap tingkat kepuasan wisatawan yang berkunjung ke obyek wisata Candi Prambanan dan Ratu Boko di Kabupaten Sleman, Yogyakarta. 


\section{TINJAUAN PUSTAKA}

1.1. Tingkat Kepuasan

Kepuasan merupakan keseimbangan atara harapan dengan persepsi seseorang, sedangkan (Engel,1995) berpendapat bahwa kepuasaan adalah tingkat perasaan seseorang setelah membandingkan kinerja yang dirasakan dengan harapan. Kepuasan merupakan suatu fungsi yang bertingkat secara relative dari suatu harapan dan atau suatu penampakan hasil yang diterima. Seseorang akan memiliki pengalaman dalam satu atau beberapa jenis kepuasan, jika hasil yang diperoleh lebih dari yang diharapkan, maka orang tersebut akan mendapatkan kepuasan pada tingkat tinggi (sangat puas). Jika hasil yang diterima sama dengan yang yang diharapkan maka orang tersbut akan merasa puas, dan jika hasil yang diterima lebih kecil dari hasil yang diharapkan maka orang tersebut merasa tidak puas atau bahkan kecewa.

\subsection{Pengukuran Kepuasan}

Mengukur kepuasan atau ketidakpuasan pelanggan menurut (J.Supranto,1997) dimulai dari penentuan pelanggan, kemudian dimonitor dari tingkat kualitas yang diinginkan dan akhirnya merumuskan strategi. Demikian pula pemilihan dan aplikasi pengukuran harus mencerminkan masalah yang diteliti. Selanjutnya dikatakan bahwa pengukuran kepuasaan pelanggan menyangkut tiga faktor yaitu: 1). Pilihan tentang ukuran kinerja yang tepat, 2). Proses pengukuran secara normaatif 3). Instrumen dan teknik pengukuran yang digunakan dapat menciptakan indikator.

Di dalam pengukuran kepuasan dikenal tiga jenis ukuran kinerja yaitu:

1). Ukuran kinerja diskriptif yang menyaajikan wawasan tentang operasi suatu sistem tanpa memilih kualitas dari operasi.

2). Ukuran kinerja evaluatife yang menyajikan suatu norma atau ukuran yang digunakan sebagai pedoman untuk menilai keadaan sebenarnya.

3). Ukuran kinerja ekonomis yang merupakan bagian dari evaluasi kinerja berbasiskan ekonomis.

Menurutnya harapan juga dapat dibentuk dari pengalaman masa lalu, komentar dari kerabat, serta janji dan informasi dari penyedia jasa dan pesaing. Kepuasan pelanggan dapat digambarkan dengan suatu sikap pelanggan berupa derajat kesukaan (kepuasan) dan ketidaksukaan (ketidakpuasan) pelanggan terhadap pelayanan atau jasa yang pernah dirasakan sebelumnya. Pengukuran kepuasan menurut (J. Supranto,1997) adalah: Sangat puas diberi nilai 5 , memuaskan biberi nilai 4 , kurang puas diberi nilai 3 , tidak puas diberi nilai 2 , dan sangat tidak puas diberi nilai 1 .

\subsection{Faktor-faktor yang mempengaruhi Kepuasaan}

Menurut (Engel,1995) kepuasan dipengaruhi oleh faktor-faktor dari dalam dan dari luar. Faktor dari dalam antara lain : sumber daya, pendidikan, pengetahuan, sikap, gaya hidup dan demografi. Sedang faktor-faktor dari luar adalah: budaya, sosial ekonomi, pengaruh keluarga dan situasi. Dalam penelitian Tingkat Kepuasan Wisatawan Domestik Terhadap Candi Prambanan Dan Ratu Boko Di Kabupaten Sleman Daerah Istimewa Yogyakarta ini akan menggunakan faktor-faktor yang berkaitan dengan obyek wisata yaitu: biaya masuk, keindahan candi, pelayanan, keamanan dan promosi. Permintaan dalam kepariwisataan dapat dibagi atas dua, yaitu potential demand dan actual demand. Yang dimaksud potential demand adalah sejumlah orang yang berpotensi untuk melakukan perjalanan wisata (karena memiliki waktu luang dan tabungan relatif cukup). 
Sedangkan actual demand adalah orang-orang yang sedang melakukan perjalanan wisata pada suatu daerah tujuan wisata tertentu. Kedua bentuk permintaan ini perlu mendapat perhatian dalam perencanaan kegiatan promosi untuk menarik wisatawan berkunjung pada suatu daerah tujuan wisata (DTW ) tertentu (Oka A. Yoeti, 2008).

Faktor-faktor yang menentukan permintaan khusus terhadap daerah tujuan wisata tertentu yang akan dikunjungi adalah sebagai berikut:

1) Harga

Dalam kepariwisataan berlaku price differentiation secara umum sebagai suatu strategi dalam pemasaran. Faktor harga sangat menentukan dalam persaingan antara sesama tour operator. Bila perbedaan dalam fasilitas tidak begitu berbeda, calon wisatawan akan lebih suka memilih harga paket wisata yang lebih murah.

2) Daya tarik wisata/Keindahan

Pemilihan DTW lebih banyak ditentukan oleh daya tarik yang terdapat di daerah tujuan wisata yang akan dikunjungi, apakah sesuai dengan keinginan. Misalnya daya tarik orang ingin ke Yogyakarta karena ingin melihat candi Borobudur dan candi Prambanan, serta menyaksikan Sendratari Ramayana dan bukan untuk melihat Jalan Malioboro.

3) Kemudahan Berkunjung/fasilitas

Kemudahan transportasi ke daerah tujuan wisata yang akan dikunjungi akan mempengaruhi pilihan wisatawan. Biasanya, tersedianya prasarana yang memadai akan menjadi pilihan bandara yang bersih dan nyaman, jalan yang tidak berlubanglubang menuju objek wisata, tersedia listrik dan air bersih yang cukup di hotel mereka menginap.

4) Informasi dan promosi

Faktor Tourist Information Service sangat penting untuk diketahui wisatawan karena dapat menjelaskan tempat-tempat yang akan dikunjungi wisatawan, kendaraan yang akan dipakai, waktu dan apa saja yang perlu dibawa, pelayanan pemesanan tiket, perpanjangan visa, penukaran valuta asing dan sebagainya. Semuanya ini penting untuk menentukan pilihan bagi wisatawan apakah ia akan menentukan pilihan berkunjung pada DTW tersebut atau tidak.

5) Citra

Wisatawan memiliki kesan dan impian tersendiri tentang daerah tujuan wisata yang akan dikunjungi. Apakah jika berkunjung ke suatu daerah tujuan wisata tertentu akan menemukan seperti yang dibayangkan, dan terhindar dari pikiran negatif seperti ancaman gempa atau bom. Oleh sebab itu suatu obyek wisata harus memiliki citra yang bagus di mata wisatawan.

\subsection{Pengertian Pariwisata}

Secara umum pariwisata merupakan suatu perjalanan yang dilakukan seseorang untuk sementara waktu yang diselenggarakan dari suatu tempat ke tempat yang lain dengan meninggalkan tempat semula dan dengan suatu perencanaan atau bukan maksud untuk mencari nafkah di tempat yang dikunjunginya, tetapi semata-mata untuk menikmati kegiatan rekreasi untuk memenuhi keinginan yang beraneka ragam. Menurut (Kodhyat,1998) pariwisata adalah perjalanan dari suatu tempat ketempat lain, bersifat sementara, dilakukan perorangan atau kelompok, sebagai usaha mencari keseimbangan atau keserasian dan kebahagian dengan lingkungan dalam dimensi sosial, budaya, alam dan ilmu. Sedangkan (Gamal, 2002), pariwisata didefinisikan sebagai bentuk. suatu 
proses kepergian sementara dari seorang, lebih menuju ke tempat lain di luar tempat tinggalnya. Dorongan kepergiannya adalah karena berbagai kepentingan baik karena kepentingan ekonomi, sosial, budaya, politik, agama, kesehatan maupun kepentingan lain. Selanjutnya (Burkart dan Medlik, 1987) menjelaskan pariwisata sebagai suatu trasformasi orang untuk sementara dan dalam waktu jangka pendek ketujuan-tujuan di luar tempat di mana mereka biasanya hidup dan bekerja, dan kegiatan kegiatan mereka selama tinggal di tempat-tempat tujuan itu. Menurut WTO yang dimaksud dengan pariwista adalah kegiatan manusia yang melakukan perjalanan ke dan tinggal di daerah tujuan di luar lingkungan kesehariannya. Sedangkan menurut Undang - Undang RI nomor 10 tahun 2009 tentang kepariwisataan dijelaskan bahwa wisata adalah kegiatan perjalanan yang dilakukan oleh seseorang atau sekelompok orang dengan mengunjungi tempat tertentu untuk tujuan rekreasi, pengembangan pribadi, atau mempelajari keunikan daya tarik wisata yang dikunjungi dalam waktu sementara.

\subsection{Wisata Candi}

Candi Prambanan adalah kompleks candi Hindu terbesar di Indonesia yang dibangun pada abad ke-9 masehi. Candi ini dipersembahkan untuk Trimurti, tiga dewa utama Hindu yaitu Brahma sebagai dewa pencipta, Wishnu sebagai dewa pemelihara, dan Siwa sebagai dewa pemusnah. Berdasarkan prasasti Siwagrha nama asli kompleks candi ini adalah Siwagrha (bahasa Sanskerta yang bermakna Rumah Siwa), dan memang di garbagriha (ruang utama) candi ini bersemayam arca Siwa Mahadewa setinggi tiga meter yang menujukkan bahwa di candi ini dewa Siwa lebih diutamakan. Kompleks candi ini terletak di kecamatan Prambanan, Sleman dan kecamatan Prambanan, Klaten, kurang lebih 17 kilometer timur laut Yogyakarta, 50 kilometer barat daya Surakarta dan 120 kilometer selatan Semarang, persis di perbatasan antara provinsi Jawa Tengah dan Daerah Istimewa Yogyakarta. Letaknya sangat unik, Candi Prambanan terletak di wilayah administrasi desa Bokoharjo, Prambanan, Sleman, sedangkan pintu masuk kompleks Candi Prambanan terletak di wilayah adminstrasi desa Tlogo, Prambanan, Klaten. Candi ini adalah termasuk Situs Warisan Dunia UNESCO, candi Hindu terbesar di Indonesia, sekaligus salah satu candi terindah di Asia Tenggara. Arsitektur bangunan ini berbentuk tinggi dan ramping sesuai dengan arsitektur Hindu pada umumnya dengan candi Siwa sebagai candi utama memiliki ketinggian mencapai 47 meter menjulang di tengah kompleks gugusan candi-candi yang lebih kecil. Sebagai salah satu candi termegah di Asia Tenggara, candi Prambanan menjadi daya tarik kunjungan wisatawan dari seluruh dunia. Menurut prasasti Siwagrha, candi ini mulai dibangun pada sekitar tahun 850 masehi oleh Rakai Pikatan, dan terus dikembangkan dan diperluas oleh Balitung Maha Sambu, di masa kerajaan Medang Mataram, sedangkan candi boko tereletak di sebelah selatan candi prambanan dengan jarak kira-kira $1,5 \mathrm{~km}$

\subsection{Pengertian Wisatawan}

Wisatawan adalah orang yang berwisata, yaitu orang yang berpergian ke suatu tempat dengan tujuan untuk bertamasya, melihat-lihat daerah lain, menikmati sesuatu, mempelajari sesuatu, menambah ilmu pengetahuan dan pengalaman, atau melepas penat dan bersenang-senang. Wisatawan seringkali disebut dengan turis. Tujuan wisatawan dalam melakukan sebuah wisata sangat bermacam macam. Ada wisatawan yang ingin mengenal kebudayaan, ada yang dilakukan dalam rangka kunjungan kerja, ada yang dilakukan untuk melakukan penelitian di objek wisata tertentu. Objek wisata yang mereka 
pilih juga sangatlah beragam. Ada dua macam wisatawan, yaitu wisatawan mancanegara dan wisatawan domestik. Wisatawan mancanegara adalah pelancong dari luar negeri, atau orang yang bertamasya ke negeri lain. Wisatawan domestik adalah wisatawan yang berpelancong ke tempat lain tetapi masih di negaranya sendiri/dalam negeri.

\subsection{Pengertian Wisatawan Domestik}

Wisatawan domestik adalah wisatawan dalam negeri, bukan wisatawan yang datang dari negara lain. Umumnya, wisatawan domestik melakukan wisata dan berekreasi ke bagian atau wilayah lain di negaranya untuk mengetahui sesuatu yang berbeda dengan lingkungan sekitarnya. Tujuan mereka berwisata di dalam negeri biasanya hanya ingin melepas rasa penasaran akan tempat yang diyakini menakjubkan atau menyenangkan.

\subsection{Dampak Pengembangan Pariwisata}

Pariwisata merupakan suatu kegiatan yang secara langsung menyentuh dan melibatkan masyarakat, sehingga memberikan berbagai dampak terhadap masyarakat setempat. Bahkan pariwisata mampu membuat masyarakat setempat mengalami perubahan dalam berbagai aspek kehidupannya baik secara ideology, politik, ekonomi, sosial, budaya, pertahanan, dan keamanan. Hal tersebutlah yang mengakibatkan dampak akan sebuah pariwisata menjadi studi yang paling sering mendapatkan perhatian masyarakat karena sifat pariwisata yang dinamis dan melibatkan banyak pemangku kepentingan. Pariwisata tentu saja akan memberikan dampak baik itu dampak positif maupun dampak negatif. Pengembangan pariwisata dan kunjungan wisatawan yang meningkat dapat menimbulkan dampak atau pengaruh positif maupun negatif dan yang terkena dampak tersebut adalah masyarakat, lingkungan, ekonomi, serta sosial (Mathieson \& Wall, 1982). Menurut (Faizun,2009), dampak pariwisata adalah perubahan-perubahan yang terjadi terhadap masyarakat sebagai komponen dalam lingkungan hidup sebelum ada kegiatan pariwisata dan setelah ada kegiatan pariwisata. Identifikasi Dampak diartikan sebagai suatu proses penetapan mengenai pengaruh dari perubahan sosial ekonomi yang terjadi terhadap masyarakat sebelum ada pengembangan pembangunan dan setelah adanya pengembangan pembangunan. Masyarakat dalam lingkungan suatu obyek wisata sangatlah penting dalam kehidupan suatu obyek wisata karena mereka memiliki kultur yang dapat menjadi daya tarik wisata, dukungan masyarakat terhadap tempat wisata berupa sarana kebutuhan pokok untuk tempat obyek wisata, tenaga kerja yang memadai dimana pihak pengelola obyek wisata memerlukannya untuk menunjang keberlangsungan hidup obyek wisata dan memuaskan masyarakat yang memerlukan pekerjaan dimana membuat kehidupan masyarakat menjadi lebih baik. Menurut (Kusudianto,1996), bahwa suatu tempat wisata yang direncanakan dengan baik, tidak hanya memberikan keuntungan ekonomi yang memperbaiki taraf, kualitas dan pola hidup komunitas setempat, tetapi juga peningkatan dan pemeliharaan lingkungan yang lebih baik. Bila dilakukan dengan benar dan tepat maka pariwisata dapat memaksimalkan keuntungan dan dapat meminimalkan permasalahan. Penduduk setempat mempunyai peran yang sangat penting dalam upaya pengembangan obyek wisata, karena penduduk setempat mau tidak mau terlibat langsung dalam aktifitas-aktifitas yang berkaitan dengan kepariwisataan di daerah tersebut. Akan tetapi apabila suatu obyek wisata tidak dikembangkan atau ditangani dengan baik atau tidak direncanakan dengan matang, dapat menyebabkan kerusakan baik secara lingkungan maupun dampak-dampak negatif terhadap ekonomi maupun sosial. 


\subsection{Kerangka Pikir}

Tingkat kepuasan wisatawan Candi Prambnanan dan Ratu Boko yang ditinjau dari 5 atribut/faktor yang ada di dalam obyek wisata tersebut yang terdiri dari: biaya masuk, keindahan candi, pelayanan, keamanan dan promosi dapat dituangkan kedalam pola pikir sebagaimana gambar 1 berikut:

\section{Gambar 1}

Faktor-faktor yang mempengaruhi tingkat kepuasan wisatawan terhadap obyek wisata Candi Prambanan dan Ratu Boko

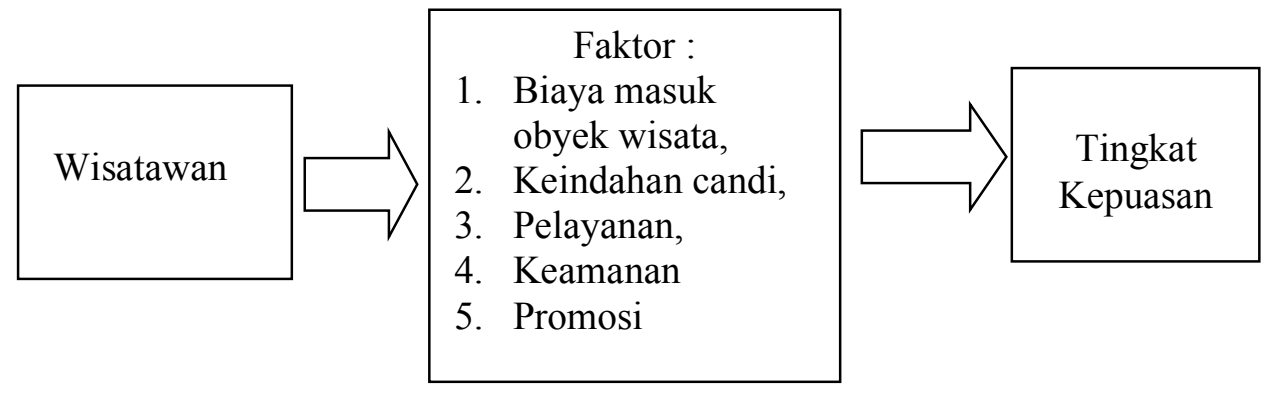

\section{METODE PENELITIAN}

2.1 Variabel dan Definisi Operasional

1). Variabel

Variabel merupakan gejala yang menjadi fokus penelitian untuk diamati. Variabel tersebut sebagai atribut dari sekelompok obyek yang mempunyai variasi antara satu dengan lainnya dalam kelompok itu (Suharsimi Arikunto, 2000). Dalam penelitian ini ada dua jenis variabel yaitu pertama variabel dependen adalah tingkat kepuasan wisatawan obyek wisata candi prambanan dan ratu boko, sedangkan variabel independen adalah adalah faktor-faktor yang mempengaruhi tingkat kepuasan wisatawan obyek wisata candi prambanan dan ratu boko terdiri dari biaya masuk, keindahan candi, pelayanan, keamanan.

2). Definisi operasional

a. Tingkat kepuasan adalah tingkat perasaan seseorang setelah membandingkan apa yang dirasakan dengan apa yang diharapan

b. Biaya masuk obyek wisata adalah harga yang harus dibayar oleh setiap pengujung untuk dapat masuk ke obyek wisata

c. Keindahan merupakan bentuk fisik kemegahan dari candi tersebut yang merupakan tatanan candi yang arstistik dengan nilai seni yang tinggi.

d. Pelayanan adalah cara melayani pengelola wisata terhadap pengunjung.

e. Keamanan adalah keadaan yang sengaja diciptakan oleh pengelola wisata agar semua pengunjung dapat merasakan aman dalam berwisata.

f. Promosi adalah bentuk penyebaran informasi dari pengelola wisata kepada masyarakat umum yang bertujuan untuk menarik wisatawan berkunjung ke candi prambanan dan ratu boko. 
3). Karakteristik pengunjung

Karakteristik pengunjung (wisatawan) domestik dilihat dari:

a. Jenis kelamin (laki-laki, perempuan)

b. Asal daerah (DIY, Luar DIY)

c. Umur (Kurang 20 th, 20 - 30 tahun, 30 - 40 tahun, 40 - 50 diatas 50)

d. Pendidikan (Tidak tamat SD/SD, SMP, SLTA, PT)

e. Pekerjaan (Petani, Pegawai Swasta, PNS, Pelajar/mahasiswa, TNI/POLRI, Wiraswasta)

\subsection{Populasi dan Sampel Responden}

1). Populasi

Populasi dalam penelitian ini adalah semua pengunjung obyek wisata Candi Prambanan dan Candi Ratu Boko di Kabupaten Sleman Daerah Istimewa Yogyakarta. Menurut (Sugiono, 2004) populasi adalah generalisasi yang terdiri atas subyek/obyek yang mempunyai kualitas dan karakteristik tertentu yang diterapkan oleh peneliti untuk dipelajari kemudian ditarik kesimpulan. Adapun populasi dalam penelitian ini adalah semua wisatawan domestik yang berwisata secara terusan di candi prambanan dan di candi ratu boko Kabupaten Sleman Daerah Istimewa Yogyakarta.

\section{2). Metode Pengambilan Sampel}

Karena jumlah populasi sangat besar dan tidak diketahui jumlahnya maka metode pengambilan sampel dilakukan dengan cara Accidental Sampling. Accidental Sampling adalah sampel yang diambil dari siapa saja yang kebetulan ada. Metode Accidental Sampling ini digunakan karena populasi yang tidak jelas (Sugiyono, 2004). Cara pengambilan sampel dalam metode ini yaitu menjadikan sampel orang yang secara kebetulan ditemui ditempat penelitian dan orang yang ditemui itu dijadikan sampel (responden).

\section{3). Jumlah Sampel}

Untuk menentukan jumlah sampel dari populasi yang tidak diketahui jumlahnya tergantung dari besarnya tingkat signifikansi dan kesalahan/ error (Sugiono,2004). Dalam hal ini menggunakan tingkat signifikansi $(\alpha)=5 \%$ dan tingkat kesalahan (error) yang terjadi maksimal 10\% maka banyaknya sampel yang diambil menggunakan rumus $\mathrm{N}=\mathrm{Z} / 4 \mathrm{MOE}^{2}$ di mana $\mathrm{N}=$ jumlah sampel, $\mathrm{Z}=$ tingkat significane, $\mathrm{MOE}=$ Margin Off Error maksimum (tingkat kesalahan maksimum yang dapat ditoleransi). Berdasarkan rumus tersebut maka besarnya $\mathrm{N}$ (sampel) adalah $1,96^{2} / 4(10 \%)^{2}=97$ merupakan sampel minimal yang diambil agar dapat mewakili populasi yang diteliti. Dal;am penelitian ini sampel yang diambil 100 responden sudah melebihi dari syarat minimal 97 responden.

\subsection{Metode Pengumpulan Data}

\section{1). Data Primer}

Data primer yaitu data yang dikumpulkan sendiri oleh perorangan atau organisasi langsung melalui obyeknya (Fandi Ciptono, 2001). Dalam pengumpulan data primer peneliti menggunakan metode kuesioner. Metode kuesioner merupakan cara pengumpulan data dengan memberikan daftar pertanyaan kepada responden 
untuk diisi (Sugiyono,2004). Dengan alternatif jawaban yang dikelompokan 5 tingkat kepuasan yaitu: Sangat Puas dengan nilai 5, Puas nilai 4, Kuang Puas 3, Tidak Puas 2 dan Sangat tidak Puas nilai 1, dari semua faktor yang diteliti yaitu biaya masuk, keindahan candi, pelayanan, keamanan dan promosi.

\section{2). Data Sekunder}

Data yang diperoleh dengan terlebih dahulu dikumpulkan dan dilaporkan oleh orang lain atau data yang sudah ada yang berasal dari dinas pariwisata, pengelola candi prambanan dan ratu boko. Data sekunder yang dibutuhkan dalam penelitian ini adalah data yang menunjukkan tentang gambaran umum obyek wisata candi prambanan dan ratu boko.

\subsection{Metode Analisis Data}

Metode Analisis yang akan digunakan dalam penelitian ini adalah:

1) Analisis Kualitatif

Metode analisis kualitatif adalah suatu analisis yang dilakukan dengan cara membuat tabel hasil jawaban responden sehingga dapat dilakukan penafsiran atas jawaban kuisioner tersebut. Dalam analisis ini akan diketahui mengenai karakteristik pengunjung obyek wisata candi prambanan dan ratu boko.

\section{2) Metode Analisis Kuantitatif}

Metode ini menggunakan perhitungan statistik atau matematika. Hasil analisis diperoleh dari informasi atau data yang digunakan untuk melakukan uji tingkat kepuasan wisatawan. Untuk analisa kuantitatif dalam penelitian ini menggunakan analisa rata-rata hitung. Analisis ini digunakan untuk menghitung nilai rata-rata hitung tingkat kepuasan wisatawan. Rumus yang digunakan adalah (Djarwanto, 1997).

$$
M e=\frac{\sum X i}{n}
$$

\section{Keterangan :}

Me : rata-rata hitung

$\mathrm{Xi}$ : nilai $\mathrm{X}$

n : jumlah data

Untuk mengetahui tingkat kepuasan wisatawan candi prambanan dan ratu boko Kabupaten Sleman Yogyakarta, menggunakan klas interval dengan rumus statistik distribusi frekuensi sebagai berikut:

a. Range $=$ data terbesar - data terkecil $=5-1=4$

b. Klas Interval Range : jumlah kelas $=4: 5=0,8$

Dari hasil kelas interval dapat di tentukan kriteria tingkat kepuasan pengunjung berikut :

\begin{tabular}{cl} 
Skor & \multicolumn{1}{c}{ Kategori } \\
$1,00-1,79$ & Sangat Tidak Puas \\
$1,80-2,59$ & Tidak Puas \\
$2,60-3,39$ & Kurang Puas \\
$3,40-4,19$ & Puas \\
$4,20-5,00$ & Sangat Puas
\end{tabular}




\subsection{Uji Validitas dan Reliabilitas}

1). Uji Validitas

Validitas menurut (Arikunto, 2002) adalah suatu ukuran yang menunjukkan tingkat kesahihan suatu instrumen penelitian. Suatu instrumen penelitian yang valid mempunyai validitas yang tinggi, sebaliknya instrumen yang kurang valid berarti memiliki validitas yang rendah, angket yang diuji validitasnya dan reliabilitasnya sebanyak 75 angket.

Pengujian menggunakan uji dua sisi dengan taraf signifikansi 0,05 dengan kriteria pengujian sebagai berikut:

- Jika $r$ hitung $\geq r$ tabel (uji 2 sisi dengan sig. 0,05) maka instrumen atau item-item pertanyaan berkorelasi signifikan terhadap skor total (dinyatakan valid)

- Jika $r$ hitung $<r$ tabel (uji 2 sisi dengan sig. 0,05) maka instrumen atau item-item pertanyaan tidak berkorelasi signifikan terhadap skor total (dinyatakan tidak valid)

Nilai $r$ tabel dapat dilihat pada tabel $r$ statistik dengan $n=75$ atau $\mathrm{df}=\mathrm{n}-2=73$ dan dengan tingkat signifikansi 0.05 maka didapat nilai $r$ tabel $=0,2272$.

Pengujian validitas menggunakan program SPSS dengan metode pearson Correlation yaitu mengkorelasikan tiap item dengan skor total item kuisioner. Hasil pengujian bahwa semua item valid, karena semua item memiliki $r$ hitung $>r$ tabel $(0,2272)$.

2). Uji Reliabilitas.

Uji reliabilitas digunakan untuk mengetahui konsistensi alat ukur, apakah alat pengukur yang digunakan dapat diandalkan dan tetap konsisten jika pengukuranya tersebut diulang. Pengujian reliabilitas yang digunakan adalah dengan menggunakan metode Cronbach Alpha. Metode Cronbach Alpa digunakan untuk mencari nilai atau bentuk skala. Suatu variabel dikatakan reliabel jika memberikan nilai cronbach alpha $\geq 0,60$ (Ghozali,2005). Jadi dasar pengambilan keputusan untuk pengujian reliabilitas adalah sebagai berikut:

a. Jika nilai Cronbach Alpa $\geq 0,60$ maka kuisioner yang diuji dinyatakan reliabel.

b. Jika nilai Cronbach Alpa $<0,60$ maka kuisioner yang diuji dinyatakan tidak reliabel.

Item-item yang tidak gugur pada uji validitas kemudian dimasukan pada uji reliabilitas. Setelah dihitung dengan bantuan program SPSS diperoleh hasil untuk kedelapan variabel, nilai di atas 0,60, maka alat ukur tersebut reliabel atau telah memenuhi syarat realibitas.

\section{ANALISA DAN PEMBAHASAN}

3.1 Analisa Kualitatif

Dalam analisa kualitatif ini bertujuan untuk mengetahui karakteristik wisatawan domestik yang berkunjung obyek wisata candi prambanan dan candi ratu boko yang didasarkan pada usia, jenis kelamin, asal daerah, pendidikan dan pekerjaan. Berdasarkan hasil kuesioner dari 100 responden diperoleh karakteristik wisatawan domestik yang berkunjung ke obyek wisata candi prambanan dan candi ratu boko secara paket sebagai berikut: 
1). Karakteristik wisatawan berdasarkan usia

Karakteristik wisatawan berdasarkan usia sebagaimana dalam tabel 4.1. berikut ini:

Tabel 4.1

Karakteristik wisatawan berdasarkan usia

\begin{tabular}{|l|c|c|c|}
\hline \multicolumn{1}{|c|}{ Umur } & Frekuensi & Prosestase & $\begin{array}{c}\text { Komulatif } \\
\text { Presentase }\end{array}$ \\
\hline Kurang 20 tahun & 22 & 22,00 & 22,00 \\
\hline$>20-30$ tahun & 29 & 29,00 & 51,00 \\
\hline$>30-40$ tahun & 21 & 21,00 & 72,00 \\
\hline$>40-50$ tahun & 13 & 13,00 & 85,00 \\
\hline diatas 50 tahun & 15 & 15,00 & 100,00 \\
\hline Jumlah & 100 & 100,00 & \\
\hline
\end{tabular}

Sumber: Data Primer yang diolah

Berdasarkan tabel 4.1. diketahui bahwa wisatawan candi prambanan dan candi ratu boko terbesar usia $>20$ - 30 tahun sebanyak 29\%, usia kurang 20 tahun sebanyak $22 \%$, usia $>30$ - 40 tahun sebanyak $21 \%$ dan usia diatas 50 tahun sebanyak $15 \%$, sedangkan yang paling sedikit usia $>40-50$ tahun yaitu $13 \%$. Hal ini sesuai dengan hasil wawancara dengan pengelola obyekwisata yang menyatakan bahwa: "Wisatawan domestik didominasi oleh wisatawan dari siswa-siswa sekolah mulai dari SD sampai SLTA terutama pada saat libur sekolah".

2). Karakteristik wisatawan berdasarkan jenis kelamin

Karakteristik wisatawan berdasarkan jenis kelamin sebagaimana dalam tabel 4.2. berikut ini:

Tabel 4.2

Karakteristik wisatawan berdasarkan jenis kelamin

\begin{tabular}{|l|c|c|c|}
\hline Jenis Kelamin & Frekuensi & Prosentase & $\begin{array}{c}\text { Komulatif } \\
\text { Presentase }\end{array}$ \\
\hline Laki-laki & 67 & 67,00 & 67,00 \\
\hline Perempuan & 33 & 33,00 & 100,00 \\
\hline Jumlah & 100 & 100,00 & \\
\hline
\end{tabular}

Sumber: Data Primer yang diolah

Berdasarkan pada tabel 4.2 tersebut diketahui bahwa jumlah wisatawan lakilaki sebanyak 67 atau 67\% dan wisatawan permpuan sebanyak 33 atau 33\% hal ini menggambarkan bahwa pengunjung jenis kelamin laki-laki lebih senang wisata ke candi prambanan dan candi ratu boko dibanding perempuan. Menurut pengelola hal ini dikarenakan masih kentalnya mitos bahwa apabila berkunjung di candi prambanan apabila memiliki pasangan/pacar pasti akan putus, sehingga wisatawan perempuan menjadi kuatir/ragu-ragu.

3). Karakteristik Wisatawan berdasarkan Asal Daerah

Karakteristik wisatawan candi prambanan dan candi ratu boko dilihat dari asal daerah yang dibedakan menjadi 2 yaitu luar DIY dan dari dalam DIY. Dari dalam DIY dibedakan asal daerah Kota Yogyakarta, Kabupaten Kulon Progo, Kabupaten Bantul, Kabupaten Gunung Kidul, dan Kabupaten Sleman sebagaimana tersebut dalam tabel 4.3. berikut ini. 
Tabel 4.3.

Karakteristik wisatawan berdasarkan asal daerah

\begin{tabular}{|l|c|c|c|}
\hline \multicolumn{1}{|c|}{ Asal Daerah } & Frekuensi & Prosentase & $\begin{array}{c}\text { Komulatif } \\
\text { Prosentase }\end{array}$ \\
\hline Kota Yogyakarta & 4 & 4,00 & 4,00 \\
\hline Kab. Kulon Progo & 12 & 12,00 & 16,00 \\
\hline Kabupaten Bantul & 11 & 11,00 & 27,00 \\
\hline Kab. Gunung Kidul & 22 & 22,00 & 49,00 \\
\hline Kabupaten Sleman & 7 & 7,00 & 56,00 \\
\hline Luar DIY & 44 & 44,00 & 100,00 \\
\hline Jumlah & 100 & 100,00 & \\
\hline
\end{tabular}

Sumber : Data Primer yang diolah

Dari tabel 4.3 tersebut diketahui bahwa jumlah wisatawan yang berkunjung ke obyek wisata candi parmbanan dan candi ratu boko menurut asal daerah terbanyak masih berasal dari dalam DIY sebesar 56\% atau 56 wisatawan dengan perincian dari mulai urutan terbanyak Kabupaten Gunung Kidul, Kabupaten Kulon Progo, Kabupaten Bantul, Kabupaten Sleman dan yang paling sedikit dari dalam DIY berasal dari Kota Yogyakarta. Sedangkan wisatawan dari luar DIY sebanyak 44\% atau 44 wisatawan.

4). Karakteristik wisatawan berdasarkan tingkat pendidikan

Karakteristik wisatawan berdasarkan tingkat pendidikan dapat dilihat sebagaimana dalam tabel 4.4 berikut ini

Tabel 4.4.

Karakteristik wisatawan berdasarkan tingkat pendidikan

\begin{tabular}{|l|c|c|c|}
\hline Tingkat Pendidikan & Frekuensi & Prosentase & $\begin{array}{c}\text { Komulatif } \\
\text { Prosentase }\end{array}$ \\
\hline Tidak bersekolah, SD & 17 & 17,00 & 17,00 \\
\hline SMP & 28 & 28,00 & 45,00 \\
\hline SLTA & 34 & 34,00 & 79,00 \\
\hline PT & 21 & 21,00 & 100,00 \\
\hline Jumlah & 100 & 100,00 & \\
\hline
\end{tabular}

Sumber: Data Primer yang diolah

Berdasarkan tabel 4.4 diketahui bahwa wisatawan candi prambanan dan candi ratu boko terbanyak dengan tingkat pendidikan SLTA sebesar 34\%, wisatawan dengan tingkat pendidikan SLTP sebanyak 28\%, wisatawan dengan tingkat pendidikan PT sebanyak $21 \%$ dan yang paling sedikit wisatawan dengan tingkat pendidikan SD sebesar 17\%.

5). Karakteristik wisatawan berdasarkan pekerjaan.

Karakteristik wisatawan berdasarkan pekerjaan sebagaimana dalam tabel 4.5 berikut: 
Tabel 4.5.

Karakteristik wisatawan berdasarkan pekerjaan

\begin{tabular}{|l|c|c|c|}
\hline \multicolumn{1}{|c|}{ Pekerjaan } & Frekuensi & $\begin{array}{c}\text { Prosentas } \\
\text { e }\end{array}$ & $\begin{array}{c}\text { Komulatif } \\
\text { Prosentase }\end{array}$ \\
\hline Petani & 11 & 11,00 & 11,00 \\
\hline Pegawai Swasta & 20 & 20,00 & 31,00 \\
\hline PNS & 21 & 21,00 & 52,00 \\
\hline Wiraswasta & 10 & 10,00 & 62,00 \\
\hline TNI/POLRI & 9 & 9,00 & 71,00 \\
\hline Pelajar/mahasiswa & 29 & 29,00 & 100,00 \\
\hline Jumlah & 100 & 100,00 & \\
\hline
\end{tabular}

Sumber: Data Primer yang diolah

Berdasarkan tabel tersebut jumlah wisatawan terbanyak dengan status pekerjaan sebagai pelajar/mahasiswa sebesar 29\% kemudian disusul PNS sebesar 21\%, pegawai swasta $20 \%$, petani $11 \%$, Wiraswata $10 \%$ dan paling sedikit dari TNI/Polri sebanyak $9 \%$.

\subsection{Analisa Kuantitatif}

Dalam analisa kuantitatif ini menggunakan mean aritmatik (rata-rata hitung) dengan tujuan untuk mengetahui tingkat kepuasan wisatawan domestik terhadap candi prambanan dan candi ratu boko dilihat dari variabel biaya masuk, keindahan candi, pelayanan, keamanan dan promosi yang dilakukan oleh pengelola candi prambanan dan candi ratu boko. Dari mean arit matik tersebut kemudian dibuat klas interval dengan rumus statistik distribusi frekuensi sebagai berikut: Range $=$ data terbesar - data terkecil $=5-1=4$. Klas Interval Range : jumlah kelas $=4: 5=0,8$. Dari hasil kelas interval dapat di tentukan kriteria tingkat kepuasan wisatawan domestik berikut: $1,00-1,80=$ Sangat Tidak Puas; $>1,80-2,60=$ Tidak Puas; $>2,60-3,40=$ Kurang Puas; $>3,40-4,20=$ Puas; $>4,20-$ $5,00=$ Sangat Puas.

1) Tingkat kepuasan wisatawan domestik terhadap harga karcis masuk/retribusi masuk obyek wisata candi prambanan dan candi ratu boko.

Tabel 4.6.

Tingkat kepuasan wisatawan domestik terhadap harga karcis masuk/retribusi masuk obyek wisata candi Prambanan dan ratu boko.

\begin{tabular}{|l|c|c|c|}
\hline \multirow{2}{*}{ Tingkat Kepuasan } & \multicolumn{3}{|c|}{ Responden } \\
\cline { 2 - 4 } & $\begin{array}{c}\text { Absolut } \\
\text { (fi) }\end{array}$ & $\begin{array}{c}\text { Skor } \\
\text { (xi) }\end{array}$ & $\begin{array}{c}\text { Jumlah } \\
\text { (fi.xi) }\end{array}$ \\
\hline Sangat Memuaskan & 25 & 5 & 125 \\
\hline Memuaskan & 44 & 4 & 176 \\
\hline Kurang Memuaskan & 10 & 3 & 30 \\
\hline Tidak Memuaskan & 18 & 2 & 38 \\
\hline Sangat Tidak Memuaskan & 3 & 1 & 3 \\
\hline Jumlah & \multicolumn{4}{|c|}{3,72} \\
\hline Rata-rata hitung & \multicolumn{4}{|c|}{} \\
\hline
\end{tabular}

Sumber: Data Primer yang diolah

Berdasarkan perhitungan mean aritmatik diperoleh nilai 3,72 yang berada pada kriteria 3,40 - 4,19 artinya wisatawan domestik candi prambanan dan candi ratu 
boko berada pada kategori "puas" atas besarnya karcis masuk/biaya masuk ke obyek wisata candi

2) Tingkat kepuasan wisatawan domestik terhadap keindahan candi prambanan dan candi ratu boko

Tabel 4.7.

Tingkat kepuasan wisatawan domestik terhadap keindahan candi prambanan dan candi ratu boko

\begin{tabular}{|l|c|c|c|}
\hline \multirow{2}{*}{ Tingkat Kepuasan } & \multicolumn{3}{|c|}{ Responden } \\
\cline { 2 - 4 } & $\begin{array}{c}\text { Abso } \\
\text { lut } \\
\text { (fi) }\end{array}$ & $\begin{array}{c}\text { Skor } \\
\text { (xi) }\end{array}$ & $\begin{array}{c}\text { Jumla } \\
\text { h } \\
\text { (fi.xi) }\end{array}$ \\
\hline Sangat Memuaskan & 59 & 5 & 295 \\
\hline Memuaskan & 24 & 4 & 96 \\
\hline Kurang Memuaskan & 15 & 3 & 45 \\
\hline Tidak Memuaskan & 2 & 2 & 4 \\
\hline Sangat Tidak Memuaskan & 0 & 1 & 0 \\
\hline Jumlah & 100 & \multicolumn{4}{|l}{} \\
\hline Rata-rata hitung & \multicolumn{4}{|l}{40} \\
\hline
\end{tabular}

Sumber: Data primer yang diolah.

Berdasarkan perhitungan mean aritmatik diperoleh nilai 4,40 yang berada pada kriteria 4,20 - 5,00 artinya wisatawan domestik yang berkunjung di obyek wisata candi prambanan dan candi ratu boko berada pada tingkat sangat puas atas keindahan candi.

3). Tingkat kepuasan wisatawan domestik terhadap pelayanan pengelola candi prambanan dan candi ratu boko

Tabel. 4.8.

Tingkat kepuasan wisatawan domestik terhadap pelayanan pengelola candi prambanan dan candi ratu boko

\begin{tabular}{|l|c|c|c|}
\hline \multirow{2}{*}{ Tingkat Kepuasan } & \multicolumn{3}{|c|}{ Responden } \\
\cline { 2 - 5 } & $\begin{array}{c}\text { Absolut } \\
\text { (fi) }\end{array}$ & $\begin{array}{c}\text { Skor } \\
\text { (xi) }\end{array}$ & $\begin{array}{c}\text { Jumlah } \\
\text { (fi.xi) }\end{array}$ \\
\hline Sangat Memuaskan & 15 & 5 & 75 \\
\hline Memuaskan & 48 & 4 & 192 \\
\hline Kurang Memuaskan & 17 & 3 & 51 \\
\hline Tidak Memuaskan & 12 & 2 & 24 \\
\hline $\begin{array}{l}\text { Sangat Tidak } \\
\text { Memuaskan }\end{array}$ & 8 & 1 & 8 \\
\hline Jumlah & 100 & \multicolumn{3}{|c|}{3,50} \\
\hline Rata-rata hitung & \multicolumn{4}{|l}{350} \\
\hline
\end{tabular}

Sumber: Data primer yang diolah.

Berdasarkan perhitungan mean aritmatik diperoleh nilai 3,50 yang berada pada kriteria 3,40 - 4,19 artinya wisatawan domestik yang berkunjung di obyek wisata candi prambanan dan candi ratu boko berada pada tingkat puas atas pelayanan yang diberikan oleh pengelola candi. 
4). Tingkat kepuasan wisatawan domestik terhadap keamanan di lokasi wisata candi prambanan dan candi ratu boko.

Tabel 4.9.

Tingkat kepuasan wisatawan domestik terhadap keamanan di lokasi wisata candi prambanan dan candi ratu boko

\begin{tabular}{|l|c|c|c|}
\hline \multirow{2}{*}{ Tingkat Kepuasan } & \multicolumn{3}{|c|}{ Responden } \\
\cline { 2 - 4 } & $\begin{array}{c}\text { Abso } \\
\text { lut } \\
\text { (fi) }\end{array}$ & $\begin{array}{c}\text { Skor } \\
\text { (xi) }\end{array}$ & $\begin{array}{c}\text { Jumlah } \\
\text { (fi.xi) }\end{array}$ \\
\hline Sangat Memuaskan & 27 & 5 & 135 \\
\hline Memuaskan & 30 & 4 & 120 \\
\hline Kurang Memuaskan & 26 & 3 & 78 \\
\hline Tidak Memuaskan & 10 & 2 & 20 \\
\hline Sangat Tidak Memuaskan & 7 & 1 & 7 \\
\hline Jumlah & 100 & & 355 \\
\hline Rata-rata hitung & \multicolumn{4}{|c|}{3,55} \\
\hline
\end{tabular}

Sumber: Data primer yang diolah.

Berdasarkan perhitungan mean aritmatik diperoleh nilai 3,55 yang berada pada kriteria 3,40 - 4,19 artinya pengunjung obyek wisata candi prambanan dan candi ratu boko merasa puas atas kondisi keamanan yang ada dilingkungan obyek wisata candi parmbanan dan candi ratu boko.

5). Tingkat kepuasan wisatawan domestik terhadap promosi yang di lakukan pihak pengelola wisata candi prambanan dan candi ratu boko

Tabel 4.10.

Tingkat kepuasan wisatawan domestik terhadap promosi yang dilakukan pihak pengelola wisata candi prambanan dan candi ratu boko

\begin{tabular}{|l|c|c|c|}
\hline Tingkat Kepuasan & \multicolumn{3}{|c|}{ Responden } \\
\cline { 2 - 4 } & $\begin{array}{c}\text { Abs } \\
\text { olut } \\
\text { (fi) }\end{array}$ & $\begin{array}{c}\text { Skor } \\
\text { (xi) }\end{array}$ & $\begin{array}{c}\text { Jumlah } \\
\text { (fi.xi) }\end{array}$ \\
\hline Sangat Memuaskan & 18 & 5 & 90 \\
\hline Memuaskan & 22 & 4 & 88 \\
\hline Kurang Memuaskan & 38 & 3 & 108 \\
\hline Tidak Memuaskan & 12 & 2 & 24 \\
\hline Sangat Tidak Memuaskan & 10 & 1 & 10 \\
\hline Jumlah & & \multicolumn{3}{|l|}{3,20} & 320 \\
\hline Rata-rata hitung & \multicolumn{3}{|l}{} \\
\hline
\end{tabular}

Sumber: Data primer yang diolah.

Berdasarkan perhitungan mean aritmatik diperoleh nilai 3,20 yang berada pada kriteria 2,60 - 3,40 artinya pengunjung obyek wisata candi prambanan dan candi ratu boko merasa kurang puas atas promosi yang dilakukan oleh pengelola obyek wisata candi parmbanan dan candi ratu boko. 
Dari kelima faktor yang dianalisis dapat dirangkum sebagaimana dalam tabel 4.11 berikut ini.

Tabel 4.11

Rangkuman nilai mean atas lima faktor yang mempengaruhi tingkat kepuasan wisatawan berkunjung ke obyek wisata candi prambanan dan candi ratu boko.

\begin{tabular}{|c|l|c|l|}
\hline No & \multicolumn{1}{|c|}{ Faktor } & $\begin{array}{c}\text { Nilai } \\
\text { mean }\end{array}$ & Tingkat kepuasan \\
\hline 1 & Biaya masuk & 3,72 & Puas \\
\hline 2 & Keindahan candi & 4,40 & Sangat puas \\
\hline 3 & Pelayanan & 3,50 & Puas \\
\hline 4 & Keamanan & 3,55 & Puas \\
\hline 5 & Promosi & 3,20 & Kurang puas \\
\hline & Jumlah & 18,37 & \\
\hline & Rerata & 3,674 & Puas \\
\hline
\end{tabular}

Sumber: Tabel $4.6 \mathrm{~s} / \mathrm{d}$ tabel 4.10

Berdasarkan tabel 4.11 tersebut diketahui bahwa, secara keseluruhan wisatawan domestik yang berkunjung ke candi prambanan dan candi ratu boko menyatakan puas. Faktor yang paling dominan mempengaruhi tingkat kepuasan wisatawan domestik berkunjung ke candi prambanan dan candi ratu boko mulai dari tingkat kepuasan yang tertinggi sampai yang terendah berturut-turut sebagai berikut: faktor keindahan, biaya masuk, keamanan, pelayanan dan faktor promosi menempati urutan terendah atas tingkat kepuasan.

\section{KESIMPULAN DAN SARAN}

4.1. Kesimpulan

Dari hasil analisa dapat disimpulkan dalam tiga hal yaitu: Karakteristik wisatawan domestik candi prambanan dan cadi ratu boko, Tingkat kepuasan wisatawan domestik candi prambanan dan ratu boko dan factor yang paling dominan memberikan sumbangan terhadap tingkat kepuasan wisatawan domestik candi prambanan dan ratu boko di Prambanan Sleman Yogyakarta.

Berdasarkan hasil penelitian seperti telah diuraikan pada bab sebelumnya dapat ditarik kesimpulan sebagai berikut:

1. Karakteristik wisatawan domestik

a. Berdasarkan usia wisatawan terbanyak usia antara 20 - 30 tahun sebesar $29 \%$ atau 29 responden, sedangkan terendah usia 40 - 50 sebanyak 13 atau $13 \%$

b. Berdasarkan jenis kelamin wisatawan $67 \%$ berjenis kelamin laki-laki dan $33 \%$ berjenis kelamin wanita

c. Berdasarkan asal daerah, sebagian besar wisatawan berasal dari (DIY), sebesar $56 \%$ sedangkan yang berasal dari luar daerah sebanyak 44 wisatawan (44\%)

d. Berdasrkan tingkat pendidikan, wisatawan dengan pendidikan SLTA paling banyak yang berkunjung ke Candi Prambanan dan ratu boko sebanyak 34\% sedangkan yang paling sedikit pendidikan SD sebesar 17\% atau 17 wisatawan

e. Berdasarkan pekerjaan, wisatawan yang berkunjung ke candi prambanan dan ratu boko paling banyak pelajar/mahasiswa yaitu $29 \%$, sedangakan yang paling sedikit dari TNI sebesar 9\%. 
2. Tingkat kepuasan wisatawan domestik terhadap candi prambanan dan ratu boko berdasar biaya masuk 3,72 (puas) ; keindahan candi 4,40 (sangat puas); pelayanan 3,50 (puas); keamanan 3,55 (puas); promosi 3,20 (kurang puas). Secara umum tingkat kepuasan berada pada kategori puas karena nilai rata-rata mean aritmaticnya sebesar 3,674 (puas)

3. Faktor yang paling dominan memberikan sumbangan terhadap tingkat kepuasan wisatawan domestik candi prambanan dan ratu boko di Prambanan Sleman Yogyakarta adalah keindahan dengan nilai mean aritmatin 4,40 (sangat puas)

\subsection{Saran}

Berdasarkan kesimpulan di atas, usul dan saran yang diharapkan dapat bermanfaat bagi pengelola obyek wisata candi prambanan dan candi ratu boko, agar jumlah pengunjung meningkat dan semakin merasakan puas adalah:

a. Meningkatkan promosi agar yang jelas sehingga informasi yang diterima oleh wisatawan sesuai dengan yang sebenarnya.

b. Menjaga kebersihan dan keaslian candi sehingga tetap menjadi unik dan indah agar wisatawan tetap terpuaskan.

c. Meningkatkan pelayanann dan keamanan agar wisatawan terpuaskan

d. Perlu mengkaji besarnya tarip/biaya masuk dengan membandingkan obyek wisata yang sejenis agar diperoleh tingkat harga yang kompetitif.

\section{DAFTAR PUSTAKA}

Arikunto, Suharsimi, 2002. Prosedur Penelitian Suatu Pendekatan Praktek. Jakarta. PT. Rineka Cipta.

Arikunto, Suharsimi. 2006. Metodologi Penelitian. Yogyakarta. Bina Aksara

Basu Swasta DH dan T Hani Handoko, 2000, Manajemen Pemasaran: Analisis Perilaku Konsumen, BPFE Yogyakarta

Burkart, A.J. dan Medlik, S. 1987. Tourism, Past, Present, and Future. London

Djarwanto PS dan Pangestu Subagyo,2007, Statistik Induktif, BPFE, Yogyakarta

Fandi Ciptono, 2001, Manajemen Jasa, Andi Ofset, Yogyakarta

Faizun, Moh. 2009. Dampak Perkembangan Kawasan Wisata Pantai Kartini Terhadap Masyarakat Setempat di Kabupaten Jepara. Tesis Program Pascasarjana Universitas Diponegoro Semarang

Ghozali, Imam, 2009. Aplikasi Analisis Multivariate Dengan Program SPSS, Edisi Keempat, Penerbit Universitas Diponegoro

Gamal Suwantoro, 2002, Dasar - Dasar Pariwisata, Penerbit Andhi, Yogyakarta 
H. Oka A. Yoeti,1997. Perencanaan dan Pengembangan Pariwisata Penerbit PT. Pradnya Paramita (cetakan pertama), Jakarta.

H. Kodhyat. 1998. Sejarah Pariwisata dan Perkembangannya di Indonesea. Jakarta. Grasindo

Hadinoto, Kusadianto,1996, Perencanaan Pengembangan Destinasi Pariwiata Jakarta. Universitas Indonesia (UI-Press).

James F. Engel, Roger D. Blacwell dan Paul W.Miniar,1995, Perilaku Konsumen, ,jilid I Binarupa Aksara, Jakarta.

J. Supranto, 1997, Metode Riset, Aplikasi Dalam Pemasaran, Fakultas Ekonomi,UI

ILenner dalam Mathieson, A and Wall, G. 1982. Tourism: Economic, Physical and Social Impact. Longman. London

Suharsimi Arikunto,2000, Manajemen Penelitian, Edisi Baru, PT Rineka Cipta, Jakarta

Sugiyono, 2004, Metode Penelitian Bisnis, CV Alfabeta, Bandung

Undang-Undang Nomor 10 Tahun 2009 tentang Kepariwisataan. Jakarta 